\title{
Biogeography of Freshwater Ostracodes in the Canadian Arctic Archipelago
}

\author{
JOAN BUNBURY',2 and KONRAD GAJEWSKI ${ }^{1}$
}

(Received 10 September 2008; accepted in revised form 15 December 2008)

\begin{abstract}
Seven species of freshwater ostracodes were identified from the sediments of 43 lakes on eight islands across the Canadian Arctic Archipelago. No ostracodes were encountered in the sediments of almost half of the lakes, and most were found at sites that had higher alkalinity. Several taxa endemic to Arctic regions are found across the Arctic Archipelago, including Candona rectangulata Alm, Limnocythere liporeticulata Delorme, and Tonnacypris glacialis Sars. The distributions of Cytherissa lacustris Sars, Cyclocypris globosa Sars, Limnocythere sappaensis Staplin, and Limnocythere (Limnocytherina) camera Delorme are more limited; this fact is attributed to differences in ion composition and concentrations.
\end{abstract}

Key words: ostracodes, distributions, biogeography, limnology, paleolimnology, Canadian Arctic

RÉSUMÉ. Sept espèces d'ostracodes d'eau douce ont été identifiées à partir des sédiments de 43 lacs répartis dans huit îles de l'archipel Arctique canadien. Aucun ostracode n'a été décelé dans les sédiments de près de la moitié des lacs, et la plupart ont été trouvés dans des lieux ayant un taux d'alcalinité plus élevé. Plusieurs taxons endémiques aux régions de l'Arctique se retrouvent à la grandeur de l'archipel Arctique, dont le Candona rectangulata Alm, le Limnocythere liporeticulata Delorme et le Tonnacypris glacialis Sars. Les répartitions de Cytherissa lacustris Sars, de Cyclocypris globosa Sars, de Limnocythere sappaensis Staplin et de Limnocythere (Limnocytherina) camera Delorme sont plus restreintes, ce qui est attribuable aux différences sur le plan de la composition et des concentrations en ions.

Mots clés : ostracodes, répartitions, biogéographie, limnologie, paléolimnologie, Arctique canadien

Traduit pour la revue Arctic par Nicole Giguère.

\section{INTRODUCTION}

Ostracodes are small, bivalved crustaceans that occur in all aquatic habitats. They typically live at the sediment-water interface and consume organic detritus. Previous work has shown that certain taxa are often associated with specific habitats (Delorme, 1990) and water chemistry (Forester, 1983; Smith, 1993). As with other aquatic organisms, species distributions are determined by ecological factors such as depth, temperature, and ionic composition and concentrations (De Deckker and Forester, 1988; Holmes, 1992; Smith and Horne, 2002). The body of an ostracode is contained within a carapace made of low-magnesium calcite, and although the body generally decomposes after the ostracode dies, the shells preserve well in lake sediments. They are therefore potentially useful organisms for reconstructing past environments (Griffiths and Holmes, 2000). However, their fossils have not been used to their full potential in studies of freshwater systems, partly because understanding of their biogeography is limited.

The biodiversity of freshwater ostracodes in the circumpolar Arctic has been documented from Russia (e.g., Bronshtein, 1988), the Siberian Arctic (e.g., Neale, 1969; Wetterich et al., 2005), Scandinavia (e.g., Alm, 1914 in
Delorme, 1968), and Greenland (e.g., Røen, 1962, 1981). In North America, the ostracode fauna has been documented from Alaska (Swain, 1963), the Northwest Territories (Tressler, 1957; Delorme and Zoltai, 1984), and the Yukon (Bunbury and Gajewski, 2005). However, most of the work in Canada has been limited to regions south of $60^{\circ} \mathrm{N}$ (Delorme, 1970a, b, c, d, 1971, 1978), and as a result, little is known about the ostracode fauna in the Canadian Arctic.

To use a group of organisms as paleoenvironmental indicators, it is necessary first to understand the ecological tolerances of the different species before attempting to infer past environments on the basis of fossils extracted from sediments. These tolerances are typically determined by sampling a geographical array of lakes and establishing which variables best explain the distribution and abundance of the organism in question. Several studies have explored the modern distribution of ostracodes and related environmental variables, including Smith (1993), Bunbury and Gajewski (2005), and Viehberg (2006); however, these data sets are limited in spatial extent and therefore provide an incomplete picture of the ecology of these organisms. More data from across the entire geographic and environmental domain of the constituent species would enhance our understanding of their modern ecology and enable their use

\footnotetext{
${ }^{1}$ Laboratory for Paleoclimatology and Climatology, Department of Geography, University of Ottawa, Ottawa, Ontario K1N 6N5, Canada

${ }^{2}$ Corresponding author: jbunbury@uottawa.ca

(C) The Arctic Institute of North America
} 
as quantitative paleoenvironmental indicators. These types of studies are particularly useful from northern regions, as the taxa that exist there today are adapted to the cold climate and have the potential to provide modern analogues for late-Pleistocene and early-Holocene sequences elsewhere. For example, Delorme and Zoltai (1984) identified sites in the Canadian North as potential modern analogues for Holocene and Pleistocene ostracode assemblages.

This study documents the freshwater ostracode taxa present across the Canadian Arctic Archipelago. We determine the environmental variables that affect their distribution and abundance in the Canadian North and provide additional data on the ecology of different species. This work will improve our ability to attempt paleoenvironmental reconstructions, as well as to document further the biodiversity of the Arctic.

\section{STUDY AREA}

Lake sediments and water chemistry data for this study were available from 43 sites across a broad area of the central and northern Canadian Arctic Archipelago (Fig. 1a). The region is divided into six geologic provinces (Fig. 1d). For example, sites on Devon Island are located on Paleozoic sedimentary rocks that are carbonate-rich (Wheeler et al., 1997), whereas most sites on Somerset Island are underlain by Precambrian sedimentary and volcanic bedrock. Sites on Victoria Island (KR06, KR08; unofficial site codes) are underlain by evaporitic rocks, or mafic intrusive rocks (diorite and gabbro; WB01) and those in the Fosheim region of Ellesmere Island are in an area with considerable Tertiary deposits.

Climate patterns in the Archipelago do not follow a latitudinal line, as the coldest temperatures occur in the northwest and on northern Ellesmere Island (Fig. 1c; Edlund and Alt, 1989). Warmer temperatures occur in the low Arctic and on the Fosheim Peninsula on Ellesmere Island and nearby Axel Heiberg Island. The growing season is short, occurring between late June and August, and continuous permafrost is widespread, limiting groundwater inputs to lakes (Woo, 1991).

\section{METHODS}

Water chemistry and sediment samples were collected from 43 lakes, either using a small inflatable raft or directly from the ice surface, between 1992 and 2004. Water sample collection and analysis followed Environment Canada (1994) protocols, the details of which are discussed in Hamilton et al. (2001), Bouchard et al. (2004), and Gajewski et al. (2005). Sediment was sampled using either an Ekman dredge or a piston corer with a five-inch diameter plastic tube, and in both cases the uppermost 1-2 cm of sediment was subsampled for ostracode valves.
Between 8 and $57.5 \mathrm{~cm}^{3}$ of sediment was subsampled and processed using standard methods for the extraction of ostracodes from lake sediments (Holmes, 2001). Sediment disaggregation depended on the nature of the sediment at each site; organic sediment samples were soaked overnight in $10 \%$ potassium hydroxide, whereas carbonate sediments were soaked for 48 hours in $5 \%$ sodium hexametaphosphate. Disaggregated sediments were sieved through $125 \mu \mathrm{m}$ stainless steel sieve or $\mathrm{Nitex}^{\odot}$ mesh. Valves were hand-picked using a $0 / 5$ brush under $10 \times$ magnification and mounted on micropaleontological slides using gum tragacanth. None of the specimens appeared to contain soft parts (e.g., appendages); however, many of the samples included well-preserved adult and juvenile valves or carapaces, suggesting that ostracodes were living in the lake at the time of sample collection (Forester, 1983). Adult valves (including carapaces) were enumerated. All specimens are stored at the Laboratory for Paleoclimatology and Climatology, Department of Geography, University of Ottawa.

Of the 43 lakes evaluated, only 24 had identifiable adult ostracodes $(\min =1 ; \max =102$, mean $=36)$. In most samples, ostracode valve concentrations were very low. Ten $\mathrm{cm}^{3}$ was initially subsampled and evaluated for adult specimens. If several individuals (i.e., more than 1 valve per $\mathrm{cm}^{3}$ ) were encountered, then subsampling was continued until the total number of valves was 50 or greater (Bunbury and Gajewski, 2005). If very few or no specimens were encountered, then subsampling for that site was suspended; however, ostracode presence at such sites was still recorded. In one case (Lake HW02), only one juvenile ostracode valve was encountered, and this information was included in the total concentration computation for that site. At four sites where ostracodes were present, the amount of sediment was depleted; therefore, counts did not reach 50 (CI07, CI16, KR06, and KR08). Identifications were achieved using $20 \times$ to $40 \times$ magnification and taxonomy followed Delorme (1968, 1970a, b, c, 1971).

A Geographic Information System was used to assign mean July air temperature (40-year means; Atkinson and Gajewski, 2002), vegetation (CAVM Team, 2003), and bedrock geology (Wheeler et al., 1997) to each site. The total concentration of ostracode valves that occurred in the 43 lakes was mapped, as were the concentrations of individual ostracode species found in the 24 lakes. Maps assist in understanding the spatial distribution of the taxa in relation to mean July temperature, vegetation, and bedrock geology.

Environmental variables considered here are those that influence ostracode distribution: temperature and lake depth, $\mathrm{pH}$, alkalinity, conductance, and ionic composition of the lake water (Griffiths and Holmes, 2000). Water temperature data were missing for lake CI03; therefore, the mean of the data set $\left(3.5^{\circ} \mathrm{C}\right)$ was substituted in that one instance. With the exception of air temperature (AirTemp), water temperature $\left(\mathrm{H}_{2} \mathrm{OTemp}\right), \mathrm{pH}$, magnesium-calcium ratio $(\mathrm{Mg} /$ $\mathrm{Ca})$, and the alkalinity-calcium ratio $(\mathrm{Alk} / \mathrm{Ca})$, all environmental variables were transformed prior to data analysis. 

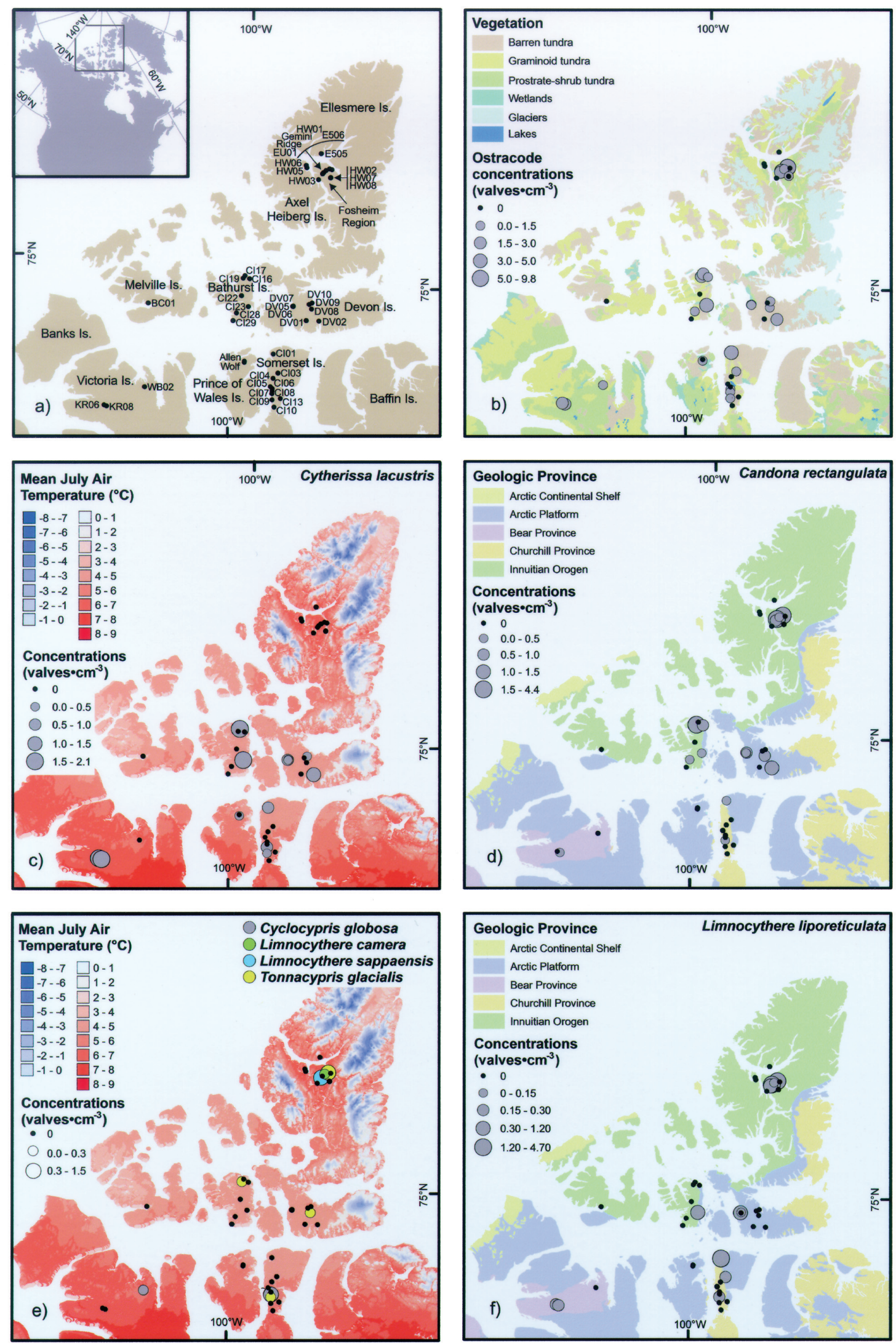

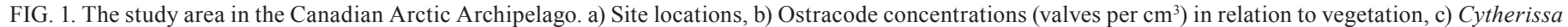

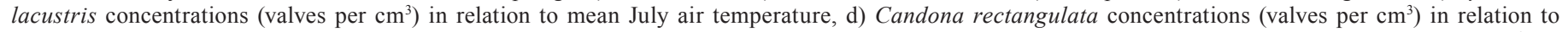

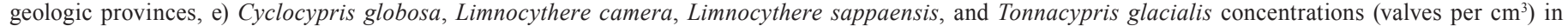

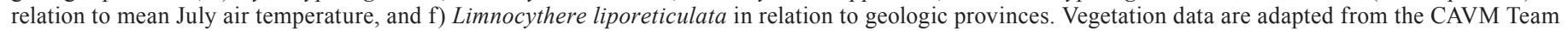
(2003), mean July air temperature (40-year average) is from Atkinson and Gajewski (2002), and geologic province data are from Wheeler et al. (1997). 
Depth, calcium $\left(\mathrm{Ca}^{2+}\right)$, magnesium $\left(\mathrm{Mg}^{2+}\right)$, sulphate $\left(\mathrm{SO}_{4}{ }^{2-}\right)$, chloride $\left(\mathrm{Cl}^{-}\right)$, and alkalinity were square root-transformed, and conductance (Cond), sodium $\left(\mathrm{Na}^{+}\right)$, and potassium $\left(\mathrm{K}^{+}\right)$ were log-transformed. Geologic provinces (GeolProv) and vegetation types ( $\mathrm{Veg}$ ) indicated on the maps were also included as explanatory variables.

A principal components analysis (PCA) was used to investigate the relations between the species and the environmental variables. This analysis combines variables together into separate linear components: the first component explains the main variation in the data, and the second component explains more of the variation, but is orthogonal to the first component (Davis, 1973). Percentage species data were log-transformed prior to analysis, and a correlation matrix was used to summarize the variation in the species data set (CANOCO 4.5; ter Braak and Šmilauer, 2002).

\section{RESULTS}

Seven taxa were encountered from 24 lakes on eight islands in the Canadian Arctic Archipelago (Table 1; Fig. $1 \mathrm{c}-\mathrm{f})$. Taxa with the greatest number of occurrences are Candona rectangulata Alm, 1914 (present in 16 lakes), Cytherissa lacustris (Sars, 1863) (13 lakes), and Limnocythere liporeticulata Delorme, 1968 (12), whereas less abundant taxa are Tonnacypris glacialis (Sars, 1890) (4), Cyclocypris globosa (Sars, 1863) (2), Limnocythere sappaensis Staplin, 1963 (1), and Limnocythere (Limnocytherina) camera Delorme, 1967 (1; Fig. 2).

C. lacustris is present in lakes at lower latitudes and absent from lakes in the High Arctic (Fig. 1c), whereas $C$. rectangulata, $L$. liporeticulata, and $T$. glacialis are present in lakes found across the entire area (Fig. 1d-f). C. globosa is limited to the more southerly sites, and L. camera and $L$. sappaensis occur only on the Fosheim Peninsula on Ellesmere Island (Fig. 1e).

Ostracode concentrations vary between 0.1 and 9.8 valves per $\mathrm{cm}^{3}$ of sediment, with the highest concentrations $\left(>4\right.$ valves per $\mathrm{cm}^{3}$ ) occurring in the Fosheim region (Fig. $1 \mathrm{~b}$; Table 1). Concentrations of $C$. rectangulata are greater in the middle and High Arctic, whereas L. liporeticulata has both high and low concentrations across the entire region.

A large amount of the total variance (44\%) is explained by the first two axes of the principal components analysis (PCA; Fig. 3). The first axis explains $26.8 \%$ of the variance in the data and includes variables related to ion concentrations, as well as the physical variables $\mathrm{H}_{2} \mathrm{OTemp}$ and Depth. The second and third axes explain $17.2 \%$ and $16.2 \%$ of the variation, respectively; GeolProv is correlated with axis two, and AirTemp and $\mathrm{K}$ are correlated with axis three (not shown). C. rectangulata, L. liporeticulata, and $T$. glacialis are taxa correlated with axis one, whereas $C$. lacustris is negatively correlated and T. glacialis is positively correlated with axis two. L. camera and $L$. sappaensis are positively correlated with axis three, whereas $T$. glacialis is negatively correlated. Lakes where ostracodes are present have higher ion concentrations, $\mathrm{pH}$, and alkalinity and are located on the right side of the tri-plot, whereas sites without ostracodes have low ion concentrations, low $\mathrm{pH}$, and low alkalinity values and are located on the left of the triplot (Fig. 3).

A majority of the lakes have a log alkalinity/calcium ratio $(\log \mathrm{Alk} / \mathrm{Ca})$ greater than 1 , particularly those that contain ostracodes; however, there are exceptions (Fig. 4). Bicarbonate $\left(\mathrm{HCO}_{3}^{-}\right)$-depleted sites (three lakes) are those with $\log (\mathrm{Alk} / \mathrm{Ca})$ less than 0 and $\log$ conductance ( $\log$ Cond) greater than 6 , whereas bicarbonate-enriched sites (four lakes) have $\log (\mathrm{Alk} / \mathrm{Ca})$ greater than 0 and $\log$ Cond greater than 6 (Curry, 1997, 1999). In these Arctic lakes, the bicarbonate-depleted sites are dominated by sulphate $\left(\mathrm{SO}_{4}{ }^{2-}\right)$, and the bicarbonate-enriched lakes are dominated or enriched by sodium $\left(\mathrm{Na}^{+}\right)$or chloride $\left(\mathrm{Cl}^{-}\right)$or both (Table 2). All other lakes have lower conductance, and most are dominated by calcium $\left(\mathrm{Ca}^{2+}\right)$, which is more characteristic of freshwater lakes (Kalff, 2002).

Convex hulls indicating species distributions as a function of conductance and the alkalinity/calcium ratio reveal the broad ranges of $C$. lacustris, C. rectangulata, and $L$. liporeticulata, and the narrow range of $T$. glacialis. $C$. lacustris can tolerate bicarbonate-depleted lake water dominated by sulphate; however, it is excluded from sites that are bicarbonate-enriched with high concentrations of sodium and chloride. In comparison, L. liporeticulata is found in lakes with high sodium and chloride concentrations. There are several sites throughout these ranges where no ostracodes were encountered. T. glacialis is limited to sites with $\log$ Alk/Ca greater than 1, and Log Cond between 4 and 6; however, this result is based on only four occurrences.

\section{DISCUSSION}

The distribution of freshwater ostracodes in the Canadian Arctic Archipelago is primarily dependent upon the alkalinity of the lake water. This is a measure of calcium carbonate in the lake water. To live and grow in a particular site, ostracodes require an available source of calcium carbonate from which to construct their shells (Delorme, 1991). Water temperature and lake depth also affect ostracode presence within a lake, but to a lesser extent. C. rectangulata, L. liporeticulata, and T. glacialis are found across the entire region because their requirements for shell creation and preservation are met and each species can tolerate the cold temperatures associated with Arctic environments. All three of these taxa are endemic to the Arctic, with C. rectangulata and T. glacialis known throughout the circumpolar region (Røen, 1962; Bronshtein, 1988; Delorme, 1991; Little and Hebert, 1997; Griffiths et al., 1998; Wetterich et al., 2008; Wojtasik, 2008), and L. liporeticulata from the Canadian Arctic (Delorme, 1991).

Sites on Victoria and Somerset islands are warmer than sites located in the middle Arctic; however, we suggest that the low concentrations of $C$. rectangulata in this area are 
TABLE 1. Ostracode taxa found in 43 lakes in the Canadian Arctic Archipelago, showing total valves and concentrations (valves per $\mathrm{cm}^{3}$ ) for each lake.

\begin{tabular}{|c|c|c|c|c|c|c|c|c|c|c|c|c|}
\hline Lake & $\begin{array}{l}\text { Lat } \\
\left({ }^{\circ} \mathrm{N}\right)\end{array}$ & $\begin{array}{l}\text { Long } \\
\left({ }^{\circ} \mathrm{W}\right)\end{array}$ & Island & $\begin{array}{l}\text { Cytherissa } \\
\text { lacustris }\end{array}$ & $\begin{array}{l}\text { Candona } \\
\text { rectangulata }\end{array}$ & $\begin{array}{l}\text { Cyclocypris } \\
\text { globosa }\end{array}$ & $\begin{array}{c}\text { Limnocythere } \\
\text { sappaensis }\end{array}$ & $\begin{array}{l}\text { e Limnocythere } \\
\text { liporeticulata }\end{array}$ & $\begin{array}{c}\text { Limnocythere } \\
\text { camera }\end{array}$ & $\begin{array}{l}\text { Tonnacypris } \\
\text { glacialis }\end{array}$ & $\begin{array}{c}\text { Total } \\
\text { valves }\end{array}$ & 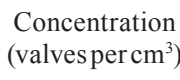 \\
\hline Allen & 73.62 & 98.47 & Prince of Wales & & & & & & & & & \\
\hline $\mathrm{BC} 01$ & 75.18 & 111.93 & Melville & & & & & & & & & \\
\hline CI01 & 73.88 & 94.87 & Somerset & 10 & 1 & & & 39 & & & 50 & 4.17 \\
\hline $\mathrm{CI} 03$ & 73.21 & 94.32 & Somerset & & & & & 6 & & & 6 & 0.20 \\
\hline CI04 & 73.03 & 94.93 & Somerset & & & & & & & & & \\
\hline CI05 & 72.73 & 95.99 & Somerset & & & & & & & & & \\
\hline CI06 & 72.67 & 95.05 & Somerset & & & & & & & & & \\
\hline $\mathrm{CI} 07$ & 72.59 & 95.06 & Somerset & & & 32 & & & & & 32 & 1.45 \\
\hline CI08 & 72.49 & 95.09 & Somerset & 30 & 15 & & & 10 & & 2 & 57 & 0.99 \\
\hline CI09 & 72.27 & 95.09 & Somerset & 4 & & & & & & & 4 & 0.13 \\
\hline CI10 & 72.01 & 94.87 & Somerset & & & & & & & & & \\
\hline CI13 & 72.31 & 94.13 & Somerset & & & & & & & & & \\
\hline CI16 & 76.50 & 98.16 & Somerset & & 24 & & & & & & 24 & 0.61 \\
\hline CI17 & 76.60 & 98.87 & Bathurst & 54 & & & & & & & 54 & 1.80 \\
\hline CI19 & 76.51 & 99.11 & Bathurst & & 50 & & & & & 5 & 55 & 1.83 \\
\hline CI22 & 75.90 & 99.22 & Bathurst & & & & & & & & & \\
\hline CI23 & 75.53 & 98.21 & Bathurst & 63 & 6 & & & 33 & & & 102 & 3.40 \\
\hline CI28 & 75.29 & 99.80 & Bathurst & & 1 & & & & & & 1 & 0.10 \\
\hline CI29 & 75.02 & 100.20 & Bathurst & & & & & & & & & \\
\hline DV01 & 74.99 & 90.36 & Devon & & & & & & & & & \\
\hline DV02 & 74.93 & 88.68 & Devon & 28 & 29 & & & & & & 57 & 2.85 \\
\hline DV05 & 75.52 & 92.05 & Devon & 42 & 4 & & & 14 & & & 60 & 1.33 \\
\hline DV06 & 75.51 & 91.99 & Devon & 2 & 4 & & & & & & 6 & 0.60 \\
\hline DV07 & 75.53 & 91.97 & Devon & 16 & 33 & & & 4 & & & 53 & 1.06 \\
\hline DV08 & 75.37 & 89.49 & Devon & & 45 & & & & & 5 & 50 & 0.91 \\
\hline DV09 & 75.58 & 89.32 & Devon & 1 & & & & & & & 1 & 0.05 \\
\hline DV10 & 75.54 & 89.75 & Devon & & & & & & & & & \\
\hline E505 & 79.98 & 82.97 & Ellesmere & & & & & & & & & \\
\hline E506 & 80.57 & 84.47 & Ellesmere & & & & & & & & & \\
\hline EU01 & 79.90 & 84.88 & Ellesmere & & 23 & & 21 & 7 & & & 51 & 2.22 \\
\hline Gemini & 79.99 & 84.13 & Ellesmere & & 1 & & & 1 & 1 & & 3 & 0.10 \\
\hline HW01 & 80.02 & 83.39 & Ellesmere & & 44 & & & 47 & & 7 & 98 & 9.80 \\
\hline HW02 & 79.73 & 83.47 & Ellesmere & & & & & & & & $1^{1}$ & 0.10 \\
\hline HW03 & 79.73 & 85.81 & Ellesmere & & & & & & & & & \\
\hline HW05 & 80.18 & 87.69 & Axel Heiberg & & & & & & & & & \\
\hline HW06 & 80.26 & 87.77 & Axel Heiberg & & & & & & & & & \\
\hline HW07 & 79.72 & 83.52 & Ellesmere & & & & & & & & & \\
\hline HW08 & 79.72 & 83.50 & Ellesmere & & & & & & & & & \\
\hline KR06 & 71.32 & 113.97 & Victoria & 16 & & & & 2 & & & 18 & 2.25 \\
\hline KR08 & 71.31 & 113.67 & Victoria & 14 & 4 & & & 2 & & & 20 & 2.50 \\
\hline Ridge & 79.94 & 84.62 & Ellesmere & & 32 & & & 64 & & & 96 & 4.80 \\
\hline WB01 & 72.29 & 109.99 & Victoria & & & 2 & & & & & 2 & 0.20 \\
\hline Wolf & 73.58 & 98.48 & Prince of Wales & les 2 & & & & & & & 2 & 0.07 \\
\hline
\end{tabular}

${ }^{1}$ Juvenile ostracode.

related to lower alkalinity values (Fig. 1d; Table 2). In comparison, $C$. globosa is restricted to lakes in the southern portion of the study area, suggesting that the species is unable to tolerate the cooler temperatures and higher alkalinity found in our more northern sites (Fig. 1e). C. lacustris can withstand the colder mean July temperatures located in the middle Arctic, but it is absent from lakes at high latitudes, where mean July temperatures are warmer and alkalinity is higher (Fig. 1c).

Two taxa were found only once in two separate lakes on Ellesmere Island. L. sappaensis occurs at the site (EU01) that has the highest values in the data set for alkalinity, sodium, and chloride (Fig. 1e; Table 2). This taxon typically occurs in sodium-bicarbonate waters (Forester, 1983), is common in lakes on the Canadian Prairies (Delorme, 1971), and inhabits alkaline lakes in the Midwest of the United
States (Smith, 1993). Several of the lakes in the Fosheim region of Ellesmere Island have emerged from the sea, and they retain high values of sodium and chloride as a legacy of submergence (Hamilton et al., 2000). Other taxa in the assemblage at Lake EU01 are C. rectangulata and L. liporeticulata, indicating the ability of these two taxa to tolerate high values of sodium and chloride. Delorme (1991) also found $C$. rectangulata in sites that were subject to sea spray, indicating the species' tolerance for saline conditions.

$L$. camera is the second taxon found only once in this study and is one of three individuals encountered at Gemini Lake. This site has high alkalinity and conductance values (Table 2), which are attributed to elevated sodium and chloride levels (although these levels are not as high as those at Lake EU01). This taxon is rare, but it has been encountered on the Canadian Prairies (Delorme, 1971), which suggests 

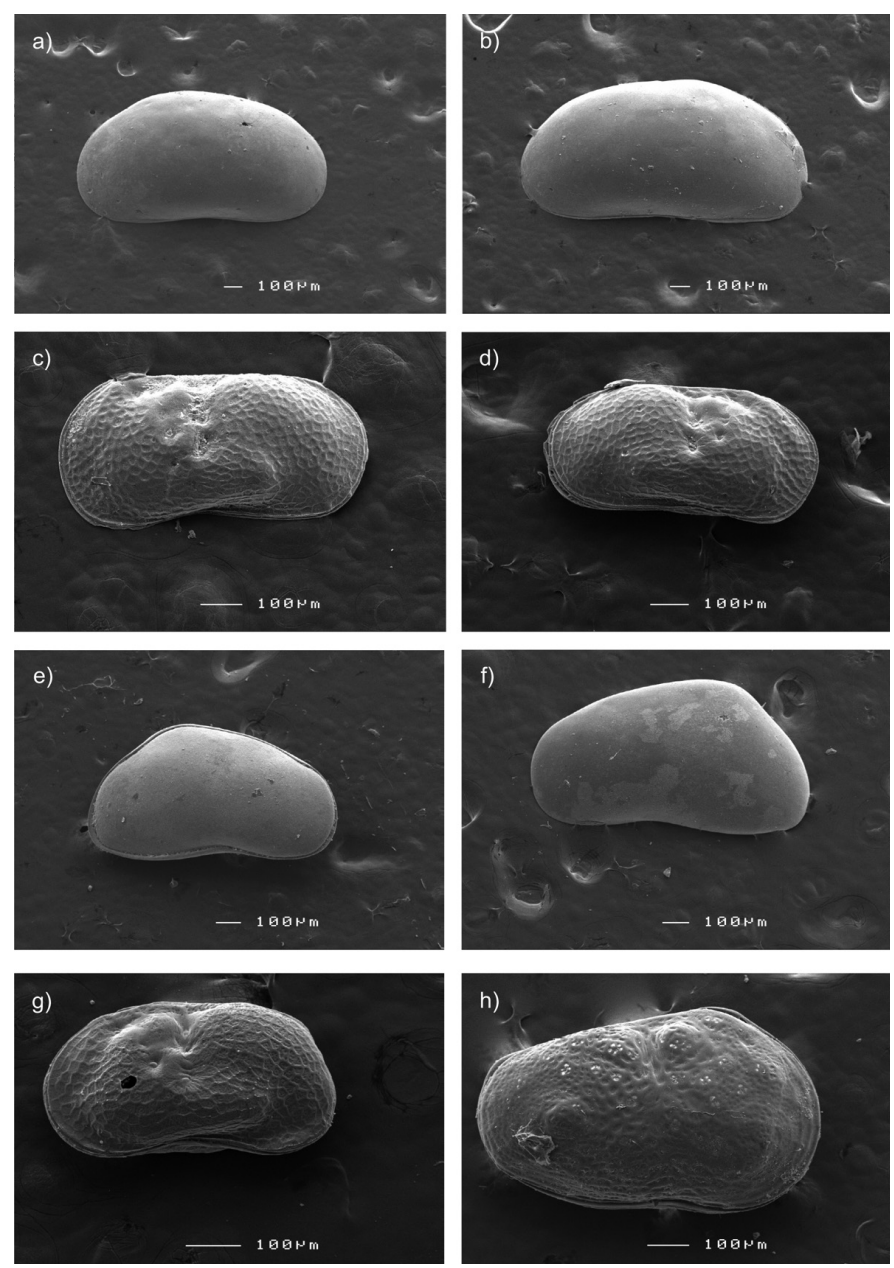

FIG. 2. Scanning electron micrographs of five ostracode taxa from the Canadian Arctic Archipelago a) Tonnacypris glacialis left valve, b) Tonnacypris glacialis right valve, c) Limnocythere liporeticulata left valve, d) Limnocythere liporeticulata carapace, e) Candona rectangulata carapace, f) Candona rectangulata left valve, g) Limnocythere sappaensis carapace, h) Cytherissa lacustris carapace. Note the varying scale bars.

an association with saline conditions. The presence of $L$. sappaensis and L. camera appears limited to sites in the Fosheim region; however, this is the only area where lakes with higher salinities were sampled. If more saline lakes from across the Canadian Arctic were to be sampled, we might be better able to determine the spatial distribution of these taxa. In addition, the identification of these rare species suggests that expanding the data set to include more lakes may identify other taxa in the region.

Ostracodes are found at sites in the Canadian Arctic that have higher alkalinity, and the widespread species $C$. rectangulata, $L$. liporeticulata, and $T$. glacialis are present across the Arctic because they can withstand the cold temperatures. The distribution of individual species appears influenced by the composition of the lake water. C. rectangulata has a broad tolerance for different ions (i.e., sulphate, sodium, and chloride); however, it is absent from sites with low ion concentrations (Fig. 3; Table 2). L. liporeticulata occurs in lakes with a wide range of alkalinity values and those dominated by sodium and chloride, but it is absent

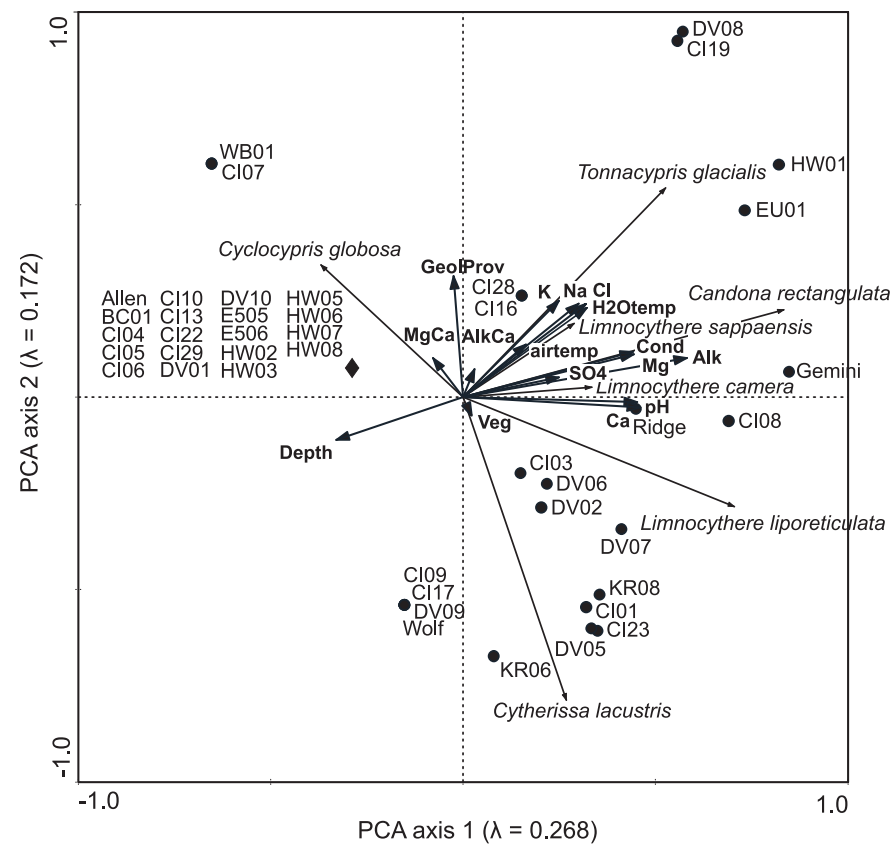

FIG. 3. Principal components analysis correlation tri-plots of lakes, ostracode species, and environmental variables. Circles represent lakes where ostracodes are present, and the diamond represents lakes (listed alongside the symbol) where ostracodes are absent.

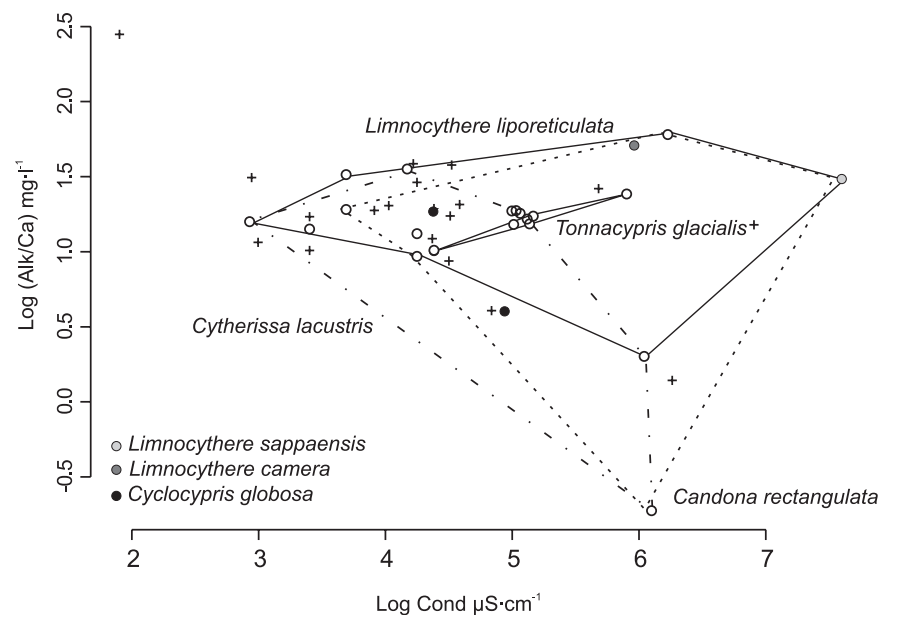

FIG. 4. Distribution of lakes in the Canadian Arctic Archipelago as a function of conductance and Alkalinity/ $\mathrm{Ca}^{2+}$ ratio. Circles indicate sites where ostracodes were present, and the plus signs indicate sites where no ostracodes were found in sediment samples from the site. Convex hulls are drawn around the locations where the more abundant species were found.

from waters with a high sulphate content. C. lacustris can tolerate elevated sulphate values, but prefers sites with low ion concentrations. In comparison, T. glacialis and C. globosa appear to have a much narrower tolerance with respect to ion content and are found at sites with lower conductance values. L. sappaensis and L. camera occupy lakes dominated by sodium and chloride, with $L$. sappaensis present only in a saline lake.

Ostracodes are neither abundant nor diverse in the Canadian Arctic Archipelago; nevertheless, several taxa are found across the region, and some taxa are found in a 


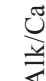

$\sum_{\substack{0 \\ \Sigma}}^{2}$

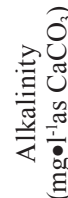

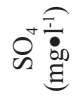

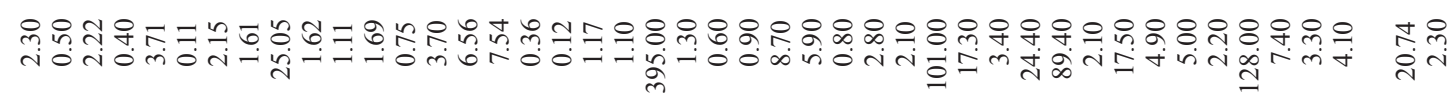

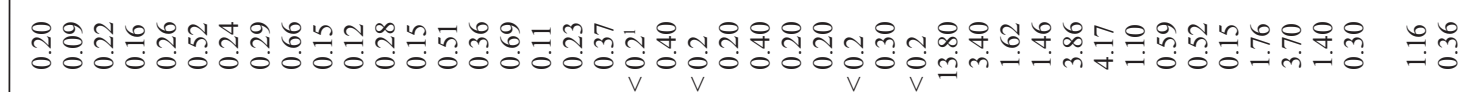

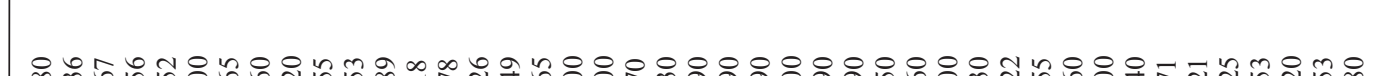

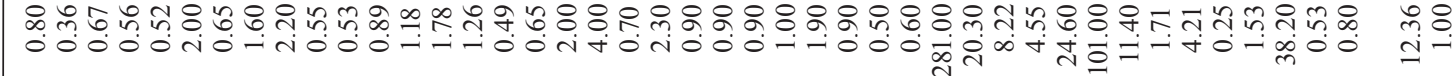

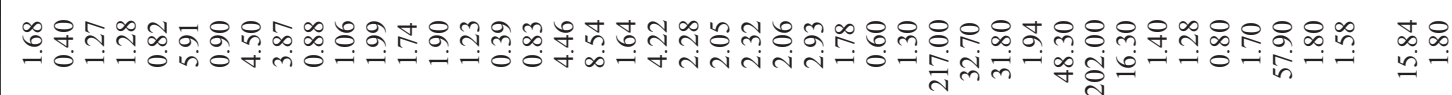

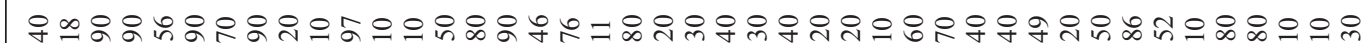

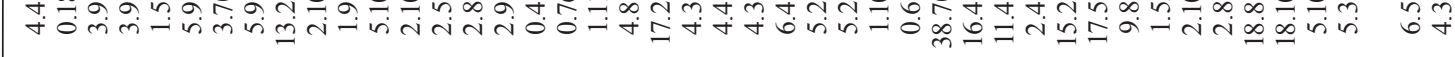

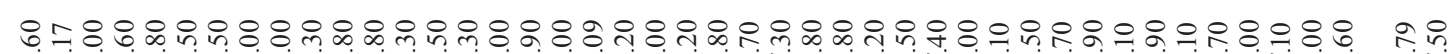

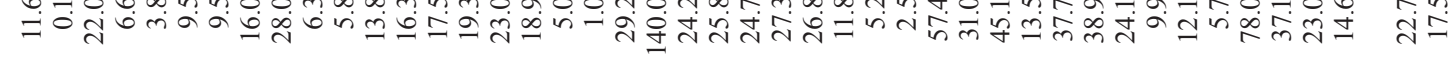

I.

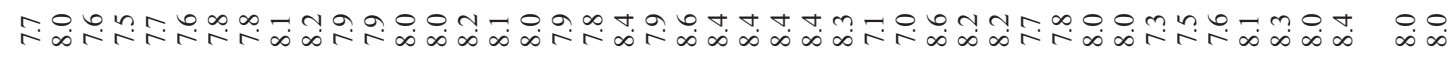

这

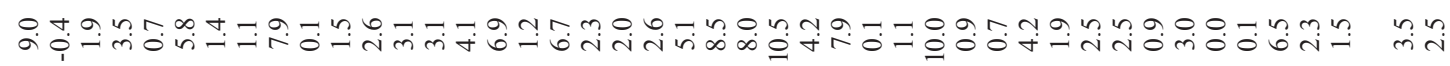

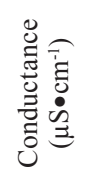

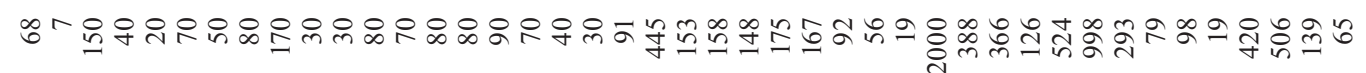

ț

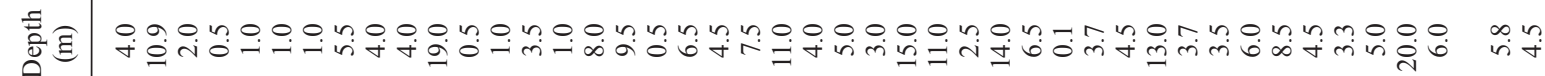

安密

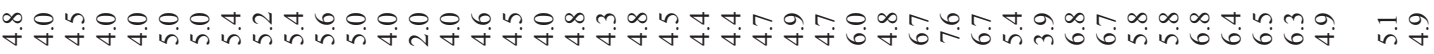

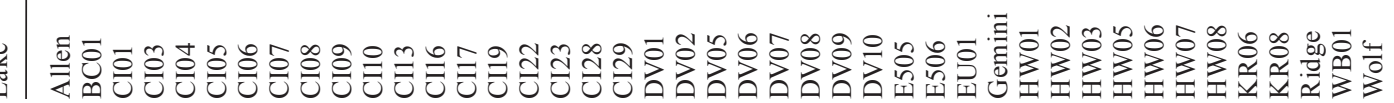

$\underset{8}{\infty}$

$\stackrel{\infty}{\stackrel{\infty}{\rightarrow}}$

1

穴

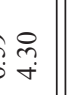


restricted group of lakes. As is the case in southern regions, those taxa that can tolerate the cold temperatures are influenced by the ion concentration of the lake waters. The results presented in this study further our knowledge of the distribution of ostracode taxa and provide data that can be used in paleoenvironmental studies in the region.

\section{ACKNOWLEDGEMENTS}

We would like to thank all of the people who assisted in the fieldwork component of this study over the years. Funding sources include an NSERC Discovery Grant, Northern Supplement, and logistic support by the Polar Continental Shelf Project (PCSP, Contribution Number 04608). We appreciate the comments from Finn Viehberg, Jonathan Holmes, and an anonymous reviewer, which improved the quality of this manuscript.

\section{REFERENCES}

Atkinson, D., and Gajewski, K. 2002. High-resolution estimation of summer surface air temperature in the Canadian Arctic Archipelago. Journal of Climate 15:3601-3614.

Bouchard, G., Gajewski, K., and Hamilton, P.B. 2004. Freshwater diatom biogeography in the Canadian Arctic Archipelago. Journal of Biogeography 31:1955-1973.

Bronshtein, Z.S. 1988. Fresh-water Ostracoda - Fauna of the USSR, crustaceans 2(1). Russian Translation Series 64. Rotterdam: A.A. Balkema.

Bunbury, J., and Gajewski, K. 2005. Quantitative analysis of freshwater ostracode assemblages in southwestern Yukon Territory, Canada. Hydrobiologia 545:117-128.

CAVM Team. 2003. Circumpolar Arctic vegetation map. Scale 1:7,500,000. Conservation of Arctic Flora and Fauna (CAFF) Map No. 1. Anchorage, Alaska: U.S. Fish and Wildlife Service.

Curry, B.B. 1997. Paleochemistry of Lakes Agassiz and Manitoba based on ostracodes. Canadian Journal of Earth Sciences 34:699-708.

1999. An environmental tolerance index for ostracodes as indicators of physical and chemical factors in aquatic habitats. Palaeogeography, Palaeoclimatology, Palaeoecology 148: $51-63$.

Davis, J.C. 1973. Statistics and data analysis in geology. Toronto: John Wiley \& Sons.

De Deckker, P., and Forester, R.M. 1988. The use of ostracodes to reconstruct continental palaeoenvironmental records. In: De Deckker, P., Colin, J.-P., and Peypouquet, J.P., eds. Ostracoda in the earth sciences. New York: Elsevier. 175-199.

Delorme, L.D. 1968. Pleistocene freshwater Ostracoda from Yukon, Canada. Canadian Journal of Zoology 46:859-876. . 1970a. Freshwater ostracodes of Canada. Part I. Subfamily Cypridinae. Canadian Journal of Zoology 48:153 - 168.

. 1970b. Freshwater ostracodes of Canada. Part II. Subfamily Cypridopsinae and Herpetocypridinae and family Cyclocyprididae. Canadian Journal of Zoology 48:253-266. 1970c. Freshwater ostracodes of Canada. Part III. Family Candonidae. Canadian Journal of Zoology 48:1099-1127.

1970d. Freshwater ostracodes of Canada. Part IV. Families Ilyocyprididae, Notodromadidae, Darwinulidae, Cytherideidae, and Entocytheridae. Canadian Journal of Zoology 48:1251-1259.

- 1971. Freshwater ostracodes of Canada. Part V. Families Limnocytheridae and Loxoconchidae. Canadian Journal of Zoology 49:43-64.

- 1978. Distribution of freshwater ostracodes in Lake Erie. Journal of Great Lakes Research 4:216-220.

1990. Freshwater ostracodes. In: Warner, B.G., ed. Methods in Quaternary ecology. Geoscience Canada Reprint Series 5. St. John's, Newfoundland: Geological Association of Canada.

. 1991. Ostracoda. In: Thorp, J.H., and Covich, A.P., eds. North American freshwater invertebrates. Toronto: Academic Press. 691-717.

Delorme, L.D., and Zoltai, S.C. 1984. Distribution of an Arctic ostracode fauna in space and time. Quaternary Research 21:65-73.

Edlund, S.A., and Alt, B.T. 1989. Regional congruence of vegetation and summer climate patterns in the Queen Elizabeth Islands, Northwest Territories, Canada. Arctic 42:3-23.

Environment Canada. 1994. Manual of analytical methods: Vol. 1: Major ions and nutrients, and Vol. 2: Trace metals. Burlington, Ontario: National Laboratory for Environmental Testing, Canadian Centre for Inland Waters.

Forester, R.M. 1983. Relationship of two lacustrine ostracode species to solute composition and salinity: Implications for paleohydrochemistry. Geology 11:435-438.

Gajewski, K., Bouchard, G., Wilson, S.E., Kurek, J., and Cwynar, L.C. 2005. Distribution of Chironomidae (Insecta: Diptera) head capsules in recent sediments of Canadian Arctic lakes. Hydrobiologia 549:131-143.

Griffiths, H.I., and Holmes, J.A. 2000. Non-marine ostracods and Quaternary paleoenvironments. Technical Guide No. 8. London: Quaternary Research Association.

Griffiths, H.I., Pietrzeniuk, E., Ruhrmann, R., Lennon, J.J., Martens, K., and Evans, J.G. 1998. Tonnacypris glacialis (Ostracoda, Cyprididae): Taxonomic position, (palaeo-) ecology, and zoogeography. Journal of Biogeography 25: 515-526.

Hamilton, P.B., Gajewski, K., McNeely, R., and Lean, D.R.S. 2000. Physical, chemical, and biological characteristics of lakes from the Slidre River basin on Fosheim Peninsula, Ellesmere Island, Nunavut. In: Garneau, M., and Alt, B.T., eds. Environmental response to climate change in the Canadian High Arctic. Geological Survey of Canada Bulletin 529. Ottawa: Geological Survey of Canada. 235-248.

Hamilton, P.B., Gajewski, K., Atkinson, D.E., and Lean, D.R.S. 2001. Physical and chemical limnology of lakes from the Canadian Arctic Archipelago. Hydrobiologia 457:133-148.

Holmes, J.A. 1992. Nonmarine ostracodes as Quaternary palaeoenvironmental indicators. Progress in Physical Geography 16:405-431. 
2001. Ostracoda. In: Smol, J.P., Birks, H.J.B., and Last, W.M., eds. Tracking environmental change using lake sediments: Zoological indicators, Vol. 4. Boston: Kluwer Academic Publishers. 125-151.

Kalff, J. 2002. Limnology: Inland water ecosystems. Upper Saddle River, New Jersey: Prentice Hall.

Little, T.J., and Hebert, P.D.N. 1997. Clonal diversity in High Arctic ostracodes. Journal of Evolutionary Biology 10:233252.

Neale, J.W. 1969. The freshwater ostracode Candona harmsworthi Scott from Franz Josef Land and Novaya Zemlya. In: Neale, J.W., ed. The taxonomy, morphology and ecology of recent Ostracoda. Edinburgh: Oliver and Boyd. 222-236.

Røen, U. 1962. Studies on freshwater Entomostraca in Greenland. II. Localities, ecology, and geographical distribution of the species. Meddelelser om Grønland 170. 249 p.

- 1981. Studies on freshwater Entomostraca in Greenland V. The fauna of the Hazen Camp study area, Ellesmere Island, N.W.T., Canada, compared to that of the Thule area, Greenland. Steenstrupia 7:321-335.

Smith, A.J. 1993. Lacustrine ostracodes as hydrochemical indicators in lakes of the north-central United States. Journal of Paleolimnology 8:121-134.

Smith, A.J., and Horne, D.J. 2002. Ecology of marine, marginal marine and nonmarine ostracodes. In: Holmes, J.A., and Chivas, A.R., eds. The Ostracoda: Applications in Quaternary research. Washington, D.C.: American Geophysical Union. 37-64.

Swain, F.M. 1963. Pleistocene Ostracoda from the Gubik Formation, Arctic Coastal Plain, Alaska. Journal of Paleontology 37:798-834.
Ter Braak, C.J.F., and Šmilauer, P. 2002. CANOCO for Windows: Software for community ordination (version 4.5). Ithaca, New York: Microcomputer Power.

Tressler, W.L. 1957. The Ostracoda of Great Slave Lake. Journal of the Washington Academy of Sciences 47:415-423.

Viehberg, F.A. 2006. Freshwater ostracod assemblages and their relationship to environmental variables in waters from Northeast Germany. Hydrobiologia 571:213-224.

Wetterich, S., Schirrmeister, L., and Pietrzeniuk, E. 2005. Freshwater ostracodes in Quaternary permafrost deposits in the Siberian Arctic. Journal of Paleolimnology 34:363-376.

Wetterich, S., Schirrmeister, L., Meyer, H., Viehberg, F.A., and Mackensen, A. 2008. Arctic freshwater ostracods from modern periglacial environments in the Lena River Delta (Siberian Arctic, Russia): Geochemical applications for palaeoenvironmental reconstructions. Journal of Paleolimnology 39:427-449.

Wheeler, J.O., Hoffman, P.F., Card, K.D., Davidson, A., Sandford, B.V., Okulitch, A.V., and Roest, W.R.C. 1997. Geological Map of Canada, Map D1860A. Ottawa: Geological Survey of Canada.

Wojtasik, B. 2008. Life cycle of Tonnacypris glacialis (Crustacea: Ostracoda). Polish Polar Research 29:33-44.

Woo, M.K. 1991. Arctic streamflow. In: Woo, M.K., and Gregor, D.J., eds. Arctic environment: Past, present and future. Proceedings of a symposium held at McMaster University, 14 15 November 1991. Hamilton, Ontario: McMaster University, Department of Geography. 105-111. 